\title{
Mathematical model for a mixed energy system as a technological alternative in the supply of electrical energy in non-interconnected areas
}

\author{
Oscar Iván Galvis Cabrera / oscarivgaca@gmail.com \\ Cristian Arturo Lee Capera / cris_Ic94@hotmail.com \\ Claudia María Cardona Londoño / cardonaclaudiamaria@gmail.com \\ Johann Alexander Hernández / jahernandezm@udistrital.edu.co \\ Universidad Distrital Francisco José de Caldas, Bogotá-Colombia
}

\begin{abstract}
The final product of this article is a mathematical model of a Mixed Energy System (MES) with Biogas-Electrical Energy (B-EE) that uses residual biomass of the pig waste, with which it is possible to estimate the amount of organic biomass necessary (or the number of animals required to produce it) to supply a farm for a certain number of hours a day, knowing the loads to be connected to the generator and taking into account the parameters necessary for the biodigester to perform its fermentation process and deliver the necessary biogas for the generator to supply power under normal conditions. The work was carried out in San Antonio del Tequendama (Cundinamarca, Colombia), a rural municipality, with a high degree of pork exploitation, and without supply of electrical energy. A small biodigester of 2.84 $\mathrm{m} 3$ was standardized, chorizo type, with a load of six pigs, C:N ratio of $1: 30$, temperature between $18-24^{\circ} \mathrm{C}$; a $\mathrm{pH}$ range of 6.8-7.2, for the supply of $2 \mathrm{~kW}$ of power, with a generator that runs with this biogas, for a consumption of $0.55 \mathrm{~m}^{3} / \mathrm{h}$.
\end{abstract}

KEYWORDS Biodigester; biogas; electric generator; model.

Modelo matemático para un sistema mixto energético como alternativa tecnológica en el suministro de energía eléctrica en zonas no interconectadas

RESUMEN El producto final de este artículo es un modelo matemático de un Sistema Mixto Energético [SME] con Biogás-Energía Eléctrica (B-EE) que utiliza biomasa residual de los desechos de porcinos, con el que se puede estimar la cantidad de biomasa orgánica necesaria (o el número de animales requerido para producirla) para abastecer una finca durante un determinado número de horas del día, conociendo las cargas que se van a conectar al generador y teniendo en cuenta los parámetros necesarios para que el biodigestor pueda realizar su proceso de fermentación y entregar el biogás necesario para que el generador suministre energía en condiciones normales. El trabajo se desarrolló en San Antonio del Tequendama (Cundinamarca, Colombia), un municipio rural, con alto grado de explotación porcina, y sin suministro de energía eléctrica. Se estandarizó un biodigestor pequeño de $2.84 \mathrm{~m} 3$, tipo chorizo, con carga de seis porcinos, relación C:N 1:30, temperatura entre $18-24^{\circ} \mathrm{C}$; en intervalo $\mathrm{PH}$ de 6.8-7.2, para el suministro de $2 \mathrm{KW}$ de potencia, con un generador que funciona con este biogás, para un consumo de $0.55 \mathrm{~m}^{3} / \mathrm{h}$.

PALABRAS CLAVE Biodigestor; biogás; generador eléctrico; modelo.
Modelo matemático para um sistema misto energético como alternativa tecnológica no fornecimento de energia elétrica em zonas não interconectadas

RESUMO O produto final deste artigo é um modelo matemático de um Sistema Misto Energético (SME) com Biogás-Energia Elétrica (B-EE) que utiliza biomassa residual a partir de dejetos de suínos, com o qual é possível estimar a quantidade de biomassa orgânica necessária (ou o número de animais necessários para a sua produção) para fornecer uma fazenda por um certo número de horas do dia, conhecendo as cargas a serem conectadas ao gerador e tendo em conta os parâmetros necessários para que o biodigestor possa realizar o processo de fermentação e entregar o biogás necessário para o gerador fornecer energia em condições normais. $\mathrm{O}$ trabalho foi desenvolvido em San Antonio del Tequendama (Cundinamarca, Colômbia), um município rural, com alto grau de produção de suínos e sem eletricidade. Foi padronizado um pequeno biodigestor de 2,84 m3, tipo chouriço, com carga de seis porcinos, relação $\mathrm{C}: \mathrm{N}$ 1:30, temperatura entre $18-24^{\circ} \mathrm{C}$; $\mathrm{PH}$ na faixa de 6.8-7.2, para o fornecimento de $2 \mathrm{KW}$ de potência, com um gerador que funciona com este biogás, para um consumo de $0,55 \mathrm{~m}^{3} / \mathrm{h}$.

PALAVRAS-CHAVE Biodigestor; biogás; gerador elétrico; modelo. 


\section{Introduction}

The administrative political division of Colombia is in departments and municipalities; however, it is also usual to divide it into subregions or provinces, this is the case of the department of Cundinamarca. The rural area covers 99.16\% of the territory of Cundinamarca (IGAC, 2016), these areas present renewable resources that have an energetic potential, due to the agricultural and livestock activities that are carried out in them. In 2012, the department had a swine population of 784.192 animals, with the highest concentration in the municipalities of San Antonio del Tequendama (13.3\%), Fusagasugá (8.1\%), Ricaurte (5.8\%), Villa Pinzón (4.8\%), Viotá (3.6\%) and Choachí (3\%), respectively (IGAC, 2016).

This project was developed in the province of Tequendama in Cundinamarca, in the municipality of San Antonio del Tequendama, located 56 kilometers to the southwest of Bogotá D.C. It is located at 1600 meters above sea level [masl], has an average temperature of $26^{\circ} \mathrm{C}$ and a relative humidity of $64 \%$. The area has swine agricultural systems; a large number of families are dedicated to pig farming but some of the farms still do not have electrical energy supply and, therefore, are part of that low percentage of areas of the country that is not supplied by the National Interconnected System [NIS].

Since the index of families dedicated to pig farming is high, several farms use biodigesters as an energy solution and use of pig waste. A sustainable solution is projected from a mixed model for the generation of electrical energy.

The research carried out is descriptive and interpretative and corresponds to the case study of a farm in the sector. It details a sequential process that includes a situational diagnosis, a detailed explanation of the technological alternative for the use and exploitation of biogas, a mathematical model that determines the production of manure and gas from a quantity of pigs available on the farm, and the autonomy of a conventional generator that works through the supply of said biogas.

The overall objective of the project was to mathematically model the operation of a Manure Management System [MMS] as appropriate technology in non-interconnected rural areas, with swine production systems starting from B-EE production. The specific objectives were determined as follows: describe the operation of a biodigester from the biogas production system to be able to characterize the model variables; characterize the conventional electrical power generator, which is on the market and allows the use of biogas from swine manure as fuel, defining the variables for the

\section{Introducción}

La división político administrativo de Colombia es en departamentos y municipios; sin embargo, también, es usual su división en subregiones o provincias, es el caso del departamento de Cundinamarca. El área rural abarca el 99,16\% del territorio de Cundinamarca (IGAC, 2016), estas zonas presentan recursos renovables que tienen un potencial energético, debido a las actividades agrícolas y pecuarias que se llevan a cabo en ellas. Para 2012, el departamento contaba con una población porcina de 784.192 animales, con mayor concentración en los municipios de San Antonio del Tequendama (13,3\%), Fusagasugá $(8,1 \%)$, Ricaurte $(5,8 \%)$, Villa Pinzón $(4,8 \%)$, Viotá $(3,6 \%)$ y Choachí (3\%), respectivamente (IGAC, 2016).

Este proyecto se desarrolló en la provincia del Tequendama en Cundinamarca, en el municipio de San Antonio del Tequendama, ubicado a 56 kilómetros al suroccidente de Bogotá D.C. Se sitúa a 1600 metros sobre el nivel del mar [msnm], su temperatura promedio es de $26^{\circ} \mathrm{C}$ y la humedad relativa del $64 \%$. La zona cuenta con sistemas agropecuarios porcícolas; un alto número de familias está dedicado a la porcicultura. Algunas de las fincas presentes en ella aún no cuentan con el suministro de energía eléctrica y, por lo tanto, hacen parte de ese bajo porcentaje de zonas del país que no es abastecido por el Sistema Interconectado Nacional [SIN].

Dado que el índice de familias dedicadas a la porcicultura es alto, varias fincas usan biodigestores como solución energética y aprovechamiento de los desechos porcinos. Se proyecta una solución sostenible a partir de un modelo mixto para la generación de energía eléctrica.

La investigación realizada es descriptiva e interpretativa y corresponde al estudio de caso en una finca del sector. Detalla un proceso secuencial realizado que incluye un diagnóstico situacional, una explicación detallada de la alternativa tecnológica para el uso y aprovechamiento del biogás, un modelo matemático que determina la producción de estiércol y de gas a partir de una cantidad de cerdos disponible en la finca, y la autonomía de un generador convencional que funciona por medio del suministro de dicho biogás.

El objetivo general del proyecto fue modelar matemáticamente el funcionamiento de un Sistema de Manejo del Estiercol [SME] como tecnología apropiada en zonas rurales no interconectadas, con sistemas productivos porcinos que parten de la producción de B-EE. Como objetivos específicos se determinaron: describir el funcionamiento de un biodigestor desde el sistema de producción de biogás, para poder caracterizar las variables del modelo; caracterizar el generador de energía eléctrica convencional, que se encuentre en el mercado y permita la utilización del biogás porcino como combustible, definiendo las variables para el modelo; y construir el escenario entre las variables teóricas y experimentales que permitan definir el modelo de optimización, en la producción de biogás y energía eléctrica con un estándar que puede ser generalizado. 


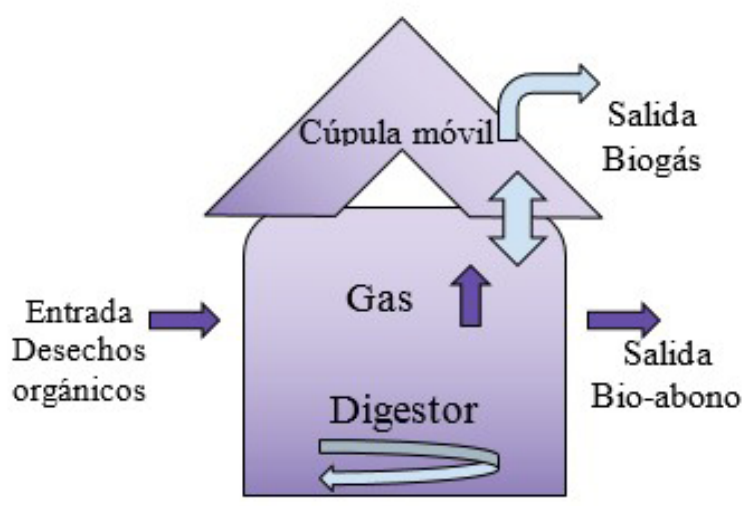

Figure 1. Scheme of Indian biodigester / Esquema del biodigestor indio

\section{Marco referencial}

Un biodigestor es un depósito o tanque completamente cerrado (hermético) en el cual la materia orgánica (i.e., desechos de animales, vegetales e incluso desechos humanos) se fermenta sin aire para obtener tres subproductos: biogás, abono orgánico y agua para riego (Guerrero, 2016).

Los tipos principales biodigestores son: planta con cúpula o campana flotante, planta con cúpula o campana fija y planta balón o biodigestor tubular.

El biodigestor indio (ver Figura 1) se compone de un digestor construido en mampostería o estructura de concreto y un depósito de gas móvil en forma de campana que flota directamente en la masa de fermentación o en un anillo de agua, dependiendo de la producción de biogás (Olaya \& González, 2009). Su principal ventaja es la larga vida útil; sus desventajas son: la susceptibilidad a la corrosión de los materiales de construcción, el alto costo de la campana y la necesidad de realizar mantenimientos periódicos.

El biodigestor chino (ver Figura 2) consta también de un digestor construido en mampostería y una cúpula, en este caso fija, completamente cerrada donde se almacena el biogás. El gas tiene que ser evacuado continuamente para aliviar la presión que se forma. De las interacciones que ocurren dentro de este biodigestor, se puede observar que la masa de fermentación es desplazada hacia el tanque de compensación, y que una vez se ha extraído el gas, la masa líquida vuelve hacia el biodigestor (Olaya \& González, 2009). Las ventajas de este tipo de biodigestor son la larga vida útil de la mampostería y la ausencia de partes metálicas en su estructura; su principal desventaja es que la presión del gas no es constante.

Por último, el biodigestor balón o tubular (también conocido como chorizo) está compuesto por un tubular de material plástico (polietileno, PVC, plastilona, etc.) que debe estar completamente sellado, con su entrada y su salida sujetas a las paredes de la planta. Este biodigestor se recomienda para zonas que presentan temperaturas constantes. En su máxima capacidad, el tubular, en su parte inferior, posee un $75 \%$ de su volumen, que corresponde model; and build the scenario between the theoretical and experimental variables that allow defining the optimization model in the production of biogas and electrical energy with a standard that can be generalized.

\section{Frame of reference}

A biodigester is a fully sealed tank (hermetic) in which organic matter (i.e., waste from animals, plants and even human waste) is fermented without air to obtain three by-products: biogas, organic fertilizer and irrigation water (Guerrero, 2016).

The main types of biodigesters are: floating drum plant, fixed dome plant and balloon plant or tubular biodigester.

The Indian biodigester (see FIgURE $\mathbf{1}$ ) is composed of a digester built in masonry or concrete structure and a bell-shaped mobile gas tank floating directly in the fermentation mass or in a ring of water, depending on the production of biogas (Olaya \& González, 2009). Its main advantage is the long service life; its disadvantages are: susceptibility to corrosion of building materials, the high cost of the bell and the need to perform periodic maintenance.

The Chinese biodigester (see FIGURE 2) also consists of a digester built in masonry and a fixed dome, completely closed where the biogas is stored. The gas must be continuously evacuated to relieve the pressure being formed. From the interactions that occur within this biodigester, it can be observed that the fermentation mass is displaced towards the compensation tank, and once the gas has been extracted, the liquid mass returns to the biodigester (Olaya \& González, 2009). The advantages of this type of biodigester are the long service life of the masonry and the absence of metallic parts in its structure; its main disadvantage is that the gas pressure is not constant.

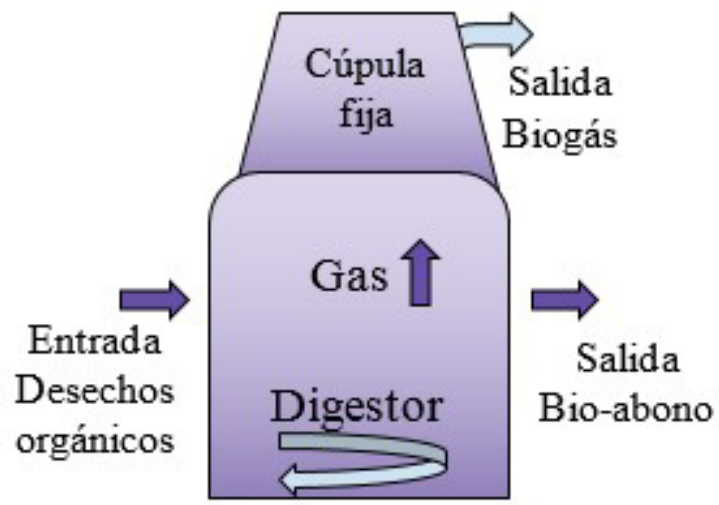

Figure 2. Scheme of biodigester with dome or fixed bell / Esquema del biodigestor con cúpula o campana fija 


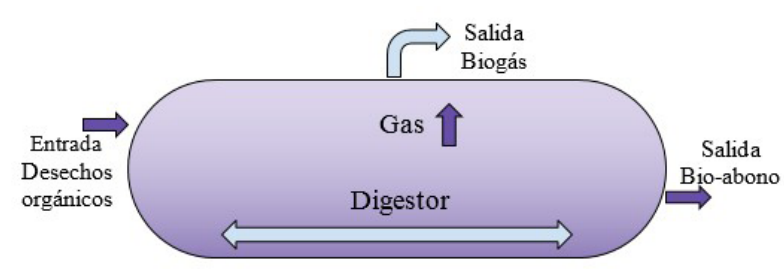

Figure 3. Scheme of balloon or tubular biodigester / Esquema del biodigestor balón o tubular

Finally, the balloon or tubular biodigester (also known as chorizo) is composed of a tubular of plastic material (polyethylene, PVC, plastic-canvas, etc.) that must be completely sealed, with its entrance and its exit attached to the walls of the plant. This biodigester is recommended for areas with constant temperatures. At its maximum capacity, the tubular, in its lower part has $75 \%$ of its volume, which corresponds to the fermentation mass, and in the upper part the remaining 25\% where the biogas is stored (see Figure 3) (Olaya \& González, 2009). Its advantages are the simplicity of its installation, the ease of transport of the materials, the low cost of its construction and its suitability for tropical areas; its major disadvantages are the low gas pressure and the susceptibility of the materials to damages.

FIGURE 4 corresponds to a balloon biodigester that is installed in the municipality of San Antonio del Tequendama, in Villa Alicia farm.

The general structure of a biodigester (FIGURE 5) consists of a load cell, that is where the process begins with the deposit of the organic waste; then, through a pipe, the waste is deposited in the fermentation chamber, which is where begins the process of organic decomposition due to anaerobic bacteria; this, in turn, through pipelines, has two outlets, one leads to the discharge cell, which is where the bio-fertilizer is obtained, the other one is the gas storage chamber (also known as reservoir in the case of the tubular biodigester) (Guerrero, 2016).

In order for the biodigester to operate optimally, it must meet certain conditions, determined by environmental factors and by the construction criteria of the biodigester. TABLE $\mathbf{1}$ presents the basic optimal conditions to be met, in relation to environmental factors.

Regarding the construction of the biodigester, it is necessary take into account the amount of organic waste, as well as the biogas production capacity it has, as well as the physical arrangement of each of the elements of the biodigester. For an area located in the tropics, as Colombia, it is feasible the construction of balloon or tubular biodigesters. The scheme shown in Figure 6 corresponds to the correct arrangement

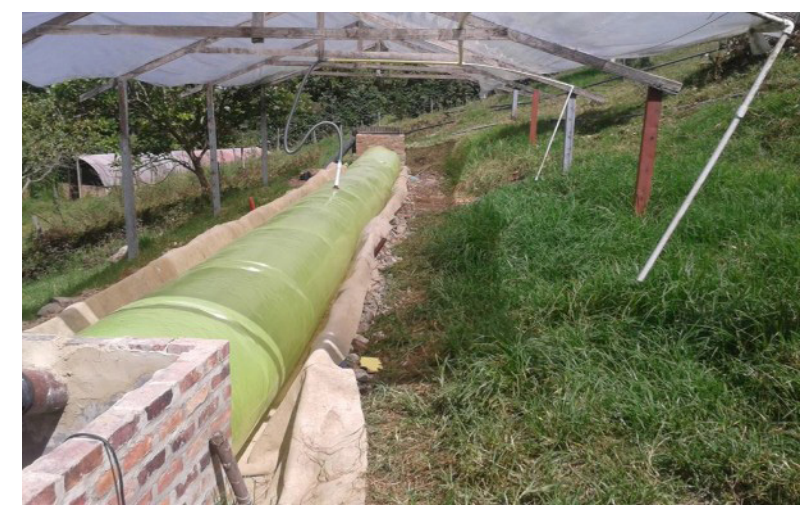

Figure 4. Balloon biodigester in Villa Alicia / Biodigestor tipo balón en Villa Alicia

a la masa de fermentación, y en la parte superior el 25\% restante, donde se almacena el biogás (ver Figura 3) (Olaya \& González, 2009). Sus ventajas son la sencillez de su instalación, la facilidad de transporte de los materiales, el bajo costo de su construcción y su adecuación para zonas tropicales; sus mayores desventajas son la baja presión del gas y la susceptibilidad de los materiales a daños.

La Figura 4 corresponde a un biodigestor tipo balón que está instalado en el municipio de San Antonio del Tequendama, en la granja Villa Alicia.

La estructura general de un biodigestor (FIGURA 5) consta de una pila de carga, ahí es donde comienza el proceso con el depósito de los desechos orgánicos; luego, mediante una tubería, los desechos se depositan en la cámara de fermentación, que es donde comienza el proceso de la descomposición orgánica debido a las bacterias anaerobias; este, a su vez, mediante ductos, tiene dos salidas, una conduce a la pila de descarga, que es donde se obtiene el bioabono, la otra es la cámara de almacenamiento del gas (también conocido como reservorio en el caso del biodigestor tubular) (Guerrero, 2016).

Para que el biodigestor tenga un óptimo funcionamiento, debe cumplir con ciertas condiciones, determinadas por los factores ambientales y por los criterios de construcción del biodigestor. En la TABLA 1 se presentan las condiciones óptimas básicas que se deben cumplir, con respecto a los factores ambientales.

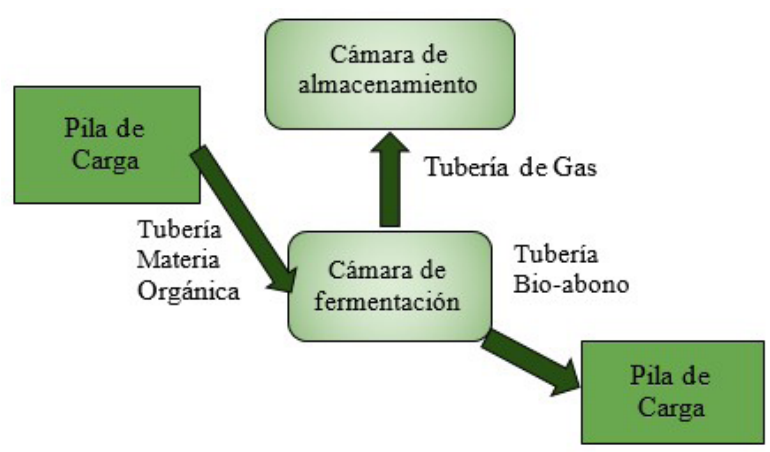

Figure 5. General structure of a biodigester / Estructura general de un biodigestor 
Table 1. Optimal values for environmental factors (Olaya \& González, 2009) / Valores óptimos para los factores ambientales

\begin{tabular}{|c|c|}
\hline Environmental factor / Factor ambiental & Optimal values / Valores óptimos \\
\hline $\mathrm{pH}$ & Between 6.5 and 7.5 \\
\hline \multirow[t]{4}{*}{ Temperature } & $0-20^{\circ} \mathrm{C} \rightarrow$ for psychophysical environment \\
\hline & / Para ambientes psicofisicos \\
\hline & $\begin{array}{r}20-45^{\circ} \mathrm{C} \rightarrow \text { for mesophilic environment / } \\
\text { Para ambientes mesófilos }\end{array}$ \\
\hline & $\begin{array}{r}45-97^{\circ} \mathrm{C} \rightarrow \text { for thermophilic environment / } \\
\text { Para ambientes termófilos }\end{array}$ \\
\hline $\begin{array}{l}\text { Carbon-to-Nitrogen ratio }(\mathrm{C}: \mathrm{N}) / \\
\text { Relación Carbono-a-Nitrógeno C:N }\end{array}$ & $20: 1-30: 1$ \\
\hline Ammonia / Amoniaco & Under $2000 \mathrm{mg} / \mathrm{l} /$ Bajo $2000 \mathrm{mg} / \mathrm{l}$ \\
\hline
\end{tabular}

En cuanto a la construcción del biodigestor, se debe tener en cuenta la cantidad de desechos orgánicos, así como la capacidad de producción de biogás que estos poseen, así como la disposición física de cada uno de los elementos del biodigestor. Para una zona del trópico, como corresponde a Colombia, es factible la construcción de biodigestores tipo balón o tubular. El esquema que se muestra en la FIGURA 6 corresponde a la correcta disposición que deben tener los componentes de un biodigestor tubular, aprovechando la fuerza de gravedad para el flujo de la materia orgánica y los desechos, así como la presión de los gases producidos, tal que no se vea afectada por la presión atmosférica.

La calidad del gas resultante a partir de cada una de las fases de la descomposición anaerobia (Hilbert, 2011), puesto que procede de fuentes de desechos orgánicos, tiene múltiples componentes químicos, muchos de ellos son de carácter tóxico, por lo que es necesario utilizar un filtro en la salida del biogás, para así obtener un gas óptimo, libre de desechos tóxicos.

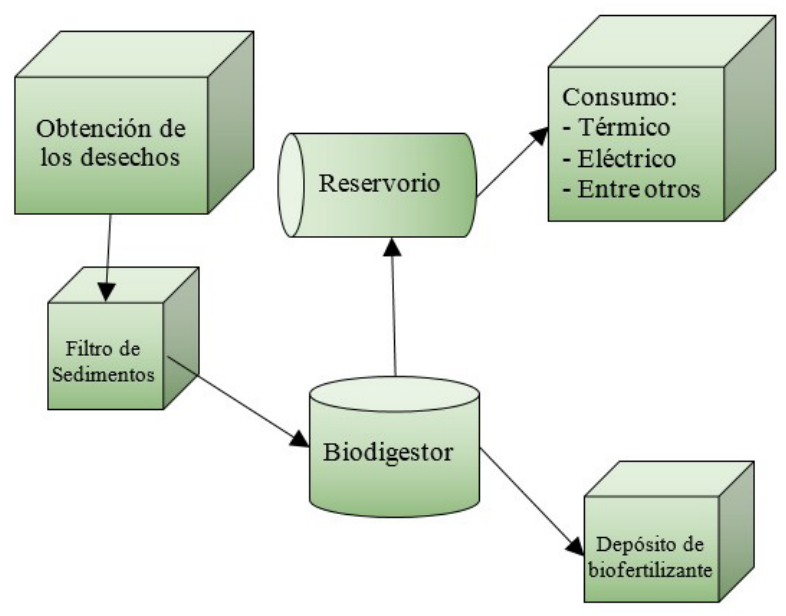

Figure 6. Optimal physical arrangement of the tubular biodigester/ Disposición física óptima del biodigestor tubular of the components of a tubular biodigester, taking advantage of the force of gravity for the flow of organic material and wastes, as well as the pressure of the gases produced, in a way that is not affected by atmospheric pressure.

The quality of the gas resulting from each of the phases of the anaerobic decomposition (Hilbert, 2011), since it comes from sources of organic waste, has multiple chemical components, many of them are of toxic nature, so it is necessary to use a filter at the biogas outlet, to obtain an optimum gas, free of toxic waste.

\section{Theory of generators}

Once the biogas production is defined for the model of a MES with B-EE, it is necessary to establish how the energy production is carried out from the biogas produced.

In power systems the production of electrical energy is carried out by using some source, whether renewable or non-renewable, which generates a potential difference high enough, and through different processes achieves the movement of a synchronous generator, these are "synchronous machines used to convert mechanical power into AC electric power" (Chapman, 2000).

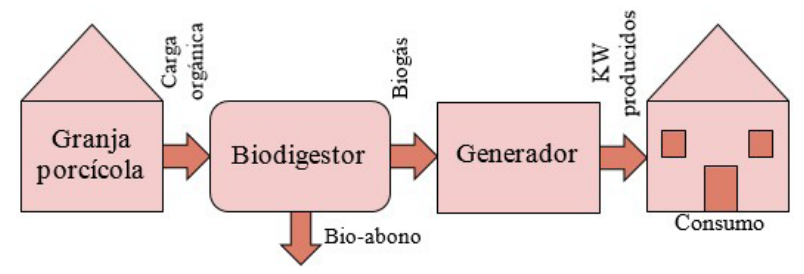

Figure 7. Schematic model of a MES with B-EE / Modelo esquemático de un SME de B-EE 
Table 2. Values obtained in study sites / Valores obtenidos en los sitios de estudio

\begin{tabular}{lrrr}
\hline Factor & Villa Letty & El Recuerdo & Villa Alicia \\
\hline Number of pigs / Cantidad de cerdos & 6 & 2 & 3 \\
Average production of animal biomass (kg) / Producción & 13,5 & 5 & 7,5 \\
promedio de biomasa animal & & & \\
Temperature $\left({ }^{\circ} \mathrm{C}\right)$ & 20 & 20 & 20 \\
Reservoir capacity $\left(\mathrm{m}^{3}\right)$ / Capacidad del reservorio & 3 & 3 & 3 \\
Biodigester capacity (liters) / Capacidad del biodigestor (litros) & 2000 & 2000 & 2000 \\
Pipe diameter $(\mathrm{cm}) /$ Diámetro del tubo & 2,4 & 2 & 2,2 \\
pH Biogas combustion (hours) & 3 & 1 & 2 \\
\hline
\end{tabular}

The MES with B-EE model to be carried out (see FIGURE 7 ) is designed for a rural area that is not part of the NIS or does not have electrical energy supply, considering the average consumption of a residence in the area.

As the generator will be fueled by the biogas from the biodigester, whose load will be that coming from wastes produced by a known quantity of pigs - and this system is designed for the energy supply of a residence--, the power supplied by the generator may correspond to nominal powers not very high, such as those granted by conventional commercial generators.

\section{Contextual framework}

In order to develop the model, three case studies are carried out, where the necessary variables are observed in the process of conversion of the pig waste to biomass and the data to establish the biogas production required to supply electrical energy is obtained from the installed load, that is assumed is the average that consumes a common residence. Data are taken from three farms dedicated to pig farming in the municipality: Villa Letty, El Recuerdo and Villa Alicia, where chorizo-type biodigesters technology had already been

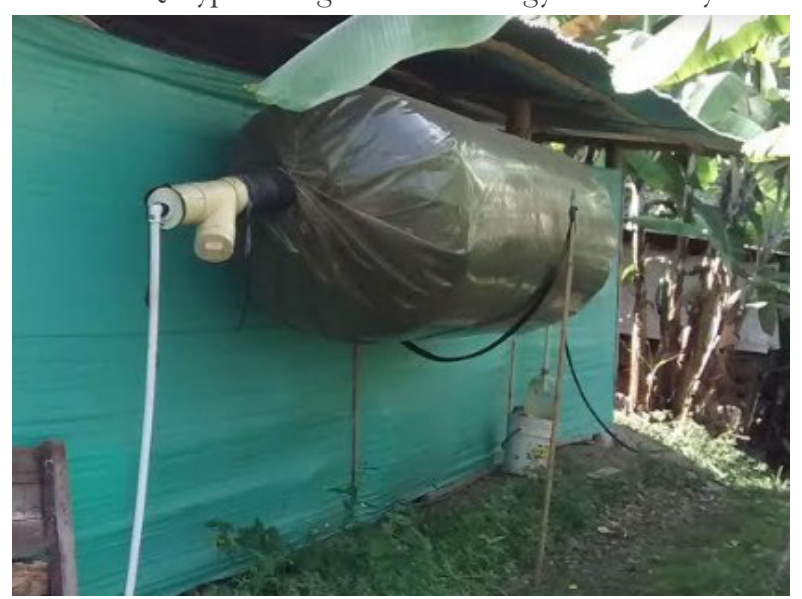

Figure 8. Chorizo-type biodigester implemented in Villa Letty / Biodigestor tipo chorizo implementado en Villa Letty

\section{Teoría de generadores}

Una vez definida la producción de biogás para el modelo de un SME de B-EE, es necesario establecer cómo se lleva a cabo la producción de energía a partir del biogás producido.

En los sistemas de potencia la producción de energía eléctrica se lleva a cabo mediante el aprovechamiento de alguna fuente, sea de carácter renovable o no renovable, que genera una diferencia de potencial lo suficientemente alta, y que mediante diferentes procesos logra el movimiento de un generador síncrono, estas son "máquinas sincrónicas utilizadas para convertir potencia mecánica en potencia eléctrica AC" (Chapman, 2000).

El modelo de SME de B-EE que se pretende realizar (ver Figura 7) está diseñado para una zona rural que no haga parte del SIN o que no cuente con el suministro de energía eléctrica, considerando el consumo promedio de una residencia de la zona.

Como el generador estará alimentado por el biogás proveniente del biodigestor, cuya carga será la de los desechos producidos por una cantidad conocida de cerdos $-\mathrm{y}$ este sistema está diseñado para el suministro de energía de una residencia-, la potencia suministrada por el generador puede corresponder a potencias nominales no muy altas, como las que otorgan generadores comerciales convencionales.

\section{Marco contextual}

Para desarrollar el modelo se llevan a cabo tres casos de estudio, en ellos se observan las variables necesarias en el proceso de conversión de los desechos del cerdo en biomasa y se obtienen los datos que permiten establecer la producción de biogás requerida para luego suministrar energía eléctrica, por medio de la carga instalada, que se asume es el promedio que consume una residencia común. Se toman datos de tres fincas dedicadas a la porcicultura en el Municipio: Villa Letty, El Recuerdo y Villa Alicia, donde ya se había implementado la tecnología de biodigestores tipo chorizo. Los datos obtenidos en estos tres lugares se presentan en la Tabla 2. Las Figuras $\mathbf{8}$ y $\mathbf{1 0}$ corresponden a los biodigestores implementados, respectivamente 


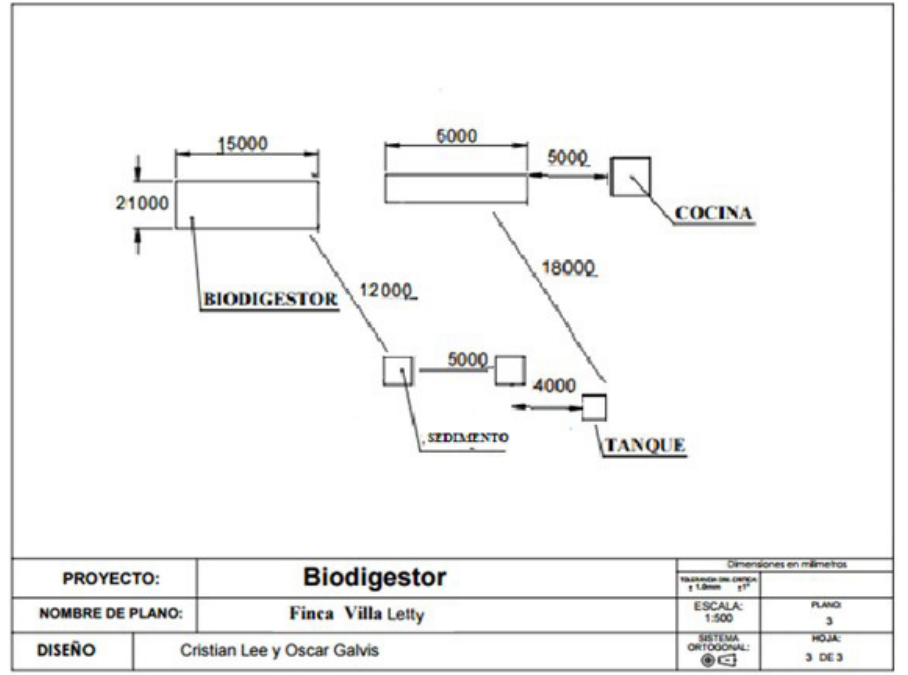

Figure 9. Location and dimensioning of the biodigester implemented in Villa Letty / Ubicación y dimensionamiento del biodigestor implementado en Villa Letty

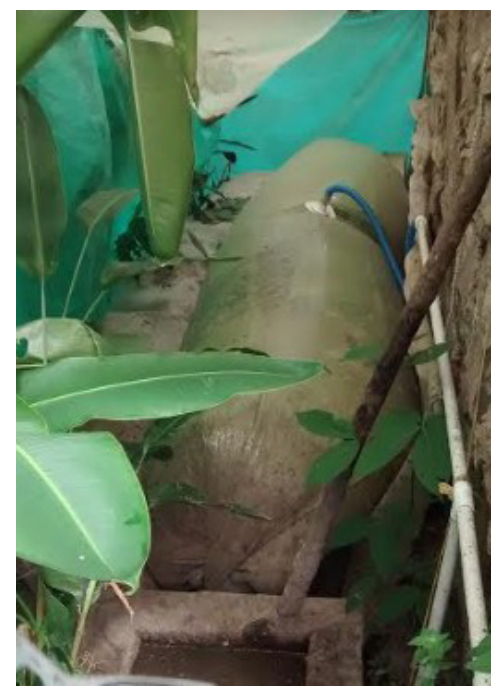

Figure 10. Chorizo-type biodigester implemented in El Recuerdo / Biodigestor tipo chorizo implementado en El Recuerdo en Villa Letty y Villa Alicia, y la Figura 9 a la disposición general de los elementos constitutivos del biodigestor, así como su dimensionamiento en Villa Letty.

\section{Restricciones}

Las restricciones para el modelo están determinadas por las especificaciones técnicas y por las condiciones del entorno del biodigestor y el generador. La TABLA 3 presenta las restricciones ambientales; la TABLA 4 las restricciones de la materia orgánica (desechos de origen porcino); y la TABLA 5 los datos correspondientes a las fincas estudiadas.

Las restricciones de construcción son: la ubicación correcta de los elementos, el dimensionamiento adecuado del biodigestor y sus componentes, y los elementos necesarios para el correcto funcionamiento del biodigestor. Las restricciones económicas son: el costo de instalación del generador y el costo de la producción de biogás. Las restricciones de los parámetros técnicos son: la eficiencia, la potencia, el tipo de combustible, la cantidad de combustible, el tiempo de suministro, la frecuencia y la tensión nominal. implemented. The data obtained in these three places are presented in Table 2. Figures $\mathbf{8}$ and $\mathbf{1 0}$ correspond to the biodigesters implemented in Villa Letty and Villa Alicia respectively, and FIGURE $\mathbf{9}$ to the general arrangement of the constituent elements of the biodigester, as well as its dimensioning in Villa Letty.

\section{Restrictions}

The restrictions for the model are determined by the technical specifications and conditions of the environment of the biodigester and the generator. TABLE 3 presents the environmental restrictions; TABLE 4 organic matter (pig waste) restrictions; and TABLE 5 the data corresponding to the farms studied.

The construction restrictions are: the correct location of the elements, the appropriate dimensioning of the biodigester and its components, and the elements necessary for the proper functioning of the biodigester. The economic restric-

Table 3. Ranges for requirements in biogas production (Olaya \& González, 2009) /

Rangos para los requisitos en la producción de biogás

\begin{tabular}{lrrr}
\hline Requirements for biogas production / & Minimum range / & Optimum / & Maximum range / \\
Requisitos para producción de biogás & Mínimo rango & Óptimo & Máximo rango \\
\hline Height (masl) / Altura (msnm) & 1500 & 1600 & 1800 \\
Environment temperature $\left({ }^{\circ} \mathrm{C}\right)$ & 21 & 32 & 38 \\
Temperatura ambiente $\left({ }^{\circ} \mathrm{C}\right)$ & & & \\
Relación C:N & 11 & 13 & 25 \\
$\mathrm{pH}$ & 6.8 & 7 & 7.2 \\
\hline
\end{tabular}


Table 4. Pig farms: digester size and biogas production (Rodriguez \& Urbina, n.d.) / Granjas de cerdos: tamaño del digestor y producción de biogás (Rodríguez \& Urbina, s.f)

\begin{tabular}{rrrr}
\hline $\begin{array}{r}\text { Pig / } \\
\text { Cerdos } \\
(\#)\end{array}$ & $\begin{array}{r}\text { Manure / } \\
\text { Estiércol (kg) }\end{array}$ & $\begin{array}{r}\text { Biodigester size } \\
\text { / Tamaño del } \\
\text { biodigestor }\left(m^{3}\right)\end{array}$ & $\begin{array}{r}\text { Volume of } \\
\text { biogas }\left(\mathrm{m}^{3} /\right. \\
\text { day })\end{array}$ \\
\hline 15 & 33.75 & 5 & 2.2 \\
24 & 54.00 & 9 & 4.0 \\
25 & 56.25 & 10 & 4.25 \\
39 & 87.75 & 15 & 7.0 \\
40 & 90.00 & 16 & 7.31 \\
83 & 186.75 & 29 & 14.9 \\
85 & 191.25 & 30 & 15.0 \\
200 & 450.00 & 50 & 36.0 \\
\hline
\end{tabular}

tions are: the cost of installing the generator and the cost of biogas production. The restrictions of the technical parameters are: efficiency, power, fuel type, fuel quantity, supply time, frequency and nominal voltage.

\section{Results}

\section{Mathematical models}

In order to carry out the mathematical model of the MES with B-EE, equation (1) corresponding to annual gas production was taken into account (Gonzaga \& Barbosa, 2014).

$$
P b=365 * n \_s * d \_s * V \_b s(1)
$$

Where:

$P b$ : Production of biogas per year [m3/year]

$n \_s:$ Total number of pigs on the farm [dimensionless]

d_s: Daily production of waste per pig [kg]

$V \_b s$ : Volume of biogas per kilo of waste $[\mathrm{m} 3 / \mathrm{kg}]$

For the daily production of biogas, it was used equation (2) as follows:

$$
P b=n \_s * d \_s * V \_b s(2)
$$

Isolating equation (2), the volume of biogas per kilo of waste is obtained, corresponding to equation (3).

$$
V \_b s=P b /\left(n \_s * d \_s\right)(3)
$$

From TABLES $\mathbf{4}$ and $\mathbf{5}$, an estimate of daily production of biogas is obtained. Replacing these values in equation (3) gives the value of the volume of biogas per kilo of manure (see TABLE 6) of the information obtained from the work of Rodríguez and Urbina (n.d.) and from the case studies of the exposed farms.
Table 5. Pig farms (case studies): digester size and biogas production / Granjas de cerdos (casos de estudio): tamaño del digestor y producción de biogás

\begin{tabular}{rrrr}
\hline $\begin{array}{r}\text { Pig / } \\
\text { Cerdos } \\
(\#)\end{array}$ & $\begin{array}{r}\text { Eanure / } \\
\text { Estiércol (kg) }\end{array}$ & $\begin{array}{r}\text { Biodigester size } \\
\text { / Tamaño del } \\
\text { biodigestor }\left(\mathrm{m}^{3}\right)\end{array}$ & $\begin{array}{r}\text { Volume of } \\
\text { biogas }\left(\mathrm{m}^{3} /\right. \\
\text { day })\end{array}$ \\
\hline 2 & 2 & 1.43 & 0.52 \\
3 & 3 & 2.50 & 0.65 \\
6 & 6 & 2.84 & 1.07 \\
\hline
\end{tabular}

\section{Resultados \\ Modelos matemáticos}

Para llevar a cabo el modelo matemático del SME con B-EE se tuvo en cuenta la ecuación (1) que corresponde a la producción anual de gas (Gonzaga \& Barbosa, 2014).

$$
P b=365 * n \_s * d \_s * V \_b s(1)
$$

Donde:

$P b$ : Producción de biogás al año [m3/año]

n_s: Número total de cerdos en la granja [adimensional]

$d \_s$ : Producción diaria de desechos por cerdo [kg]

$V \_b s$ : Volumen de biogás por kilo de desecho $[\mathrm{m} 3 / \mathrm{kg}]$

Para la producción diaria de biogás, se utilizó la ecuación (2).

$$
P b=n \_s * d \_s * V \_b s(2)
$$

Despejando de la ecuación (2), se obtiene el volumen de biogás por kilo de desecho, lo que corresponde a la ecuación (3).

$$
V \_b s=P b /\left(n \_s * d \_s\right)(3)
$$

A partir de las Tablas 4 y $\mathbf{5}$, se obtiene un estimativo de la producción de biogás diario. Reemplazando estos valores en la ecuación (3) se obtiene el valor del volumen de biogás por kilo de estiércol (ver Tabla 6) de la información obtenida del trabajo de Rodríguez y Urbina (s.f) y de las fincas casos de estudio expuestas.

Una vez obtenidos estos datos se procede a realizar el modelo matemático del SME con B-EE, estableciendo como variable de entrada la cantidad de cerdos que se tengan en una granja determinada $(\mathrm{x})$, ya que son la fuente de la materia prima para la producción de biogás.

Teniendo en cuenta las Tablas 4 y 5 , se procede por medio de la herramienta de software matemático Matlab a encontrar una ecuación del estimativo de la cantidad de estiércol que se obtiene de estos datos que corresponde a la ecuación (4); asimismo se obtuvo la ecuación (5) que corresponde a la producción de biogás, dependiendo de la variable de entrada.

$C_{E}=(31,19 * E-9) x^{4}+(11,1 * E-6) x^{3}-0.0011 x^{2}+2.2124 x+0.4093(4)$ 
Table 6. Volume of biogas per kilo of manure / Volumen de biogás por kilos de estiércol

\begin{tabular}{rrrr}
\hline $\begin{array}{r}\text { Pig / } \\
\text { Cerdos } \\
(\#)\end{array}$ & $\begin{array}{r}\text { Manure / } \\
\text { Estiércol (kg) }\end{array}$ & $\begin{array}{r}\text { Biodigester size } \\
\text { / Tamaño del } \\
\text { biodigestor }\left(m^{3}\right)\end{array}$ & $\begin{array}{r}\text { Volume of } \\
\text { biogas }\left(\mathrm{m}^{3} /\right. \\
\text { day })\end{array}$ \\
\hline 1 & 2.25 & 0.28 & $5.19 \mathrm{E}-03$ \\
2 & 5 & 0.52 & $2.16667 \mathrm{E}-03$ \\
3 & 7.5 & 0.65 & $1.20370 \mathrm{E}-03$ \\
6 & 13.5 & 1.07 & $5.50412 \mathrm{E}-04$ \\
15 & 33.75 & 5 & $1.81070 \mathrm{E}-04$ \\
24 & 54 & 9 & $1.28601 \mathrm{E}-04$ \\
25 & 56.25 & 10 & $1.25926 \mathrm{E}-04$ \\
39 & 87.75 & 15 & $8.52266 \mathrm{E}-05$ \\
40 & 90 & 16 & $8.46065 \mathrm{E}-05$ \\
83 & 186.75 & 29 & $4.00531 \mathrm{E}-05$ \\
85 & 191.25 & 30 & $3.84468 \mathrm{E}-05$ \\
200 & 450 & 50 & $1.66667 \mathrm{E}-05$ \\
\hline
\end{tabular}

Donde:

$C_{E}:$ Cantidad de Estiércol $[\mathrm{kg}]$

$x$ : Número de cerdos en la granja [adimensional]

$P_{B}=(134,99 * E-9) x^{4}+(43,62 * E-6) x^{3}+(3,8 * E-3) x^{2}+0.0832 x-0.3525(5)$

Donde:

$P_{B}$ : Producción de Biogás [m3/día]

x: Número de cerdos en la granja [adimensional]

Con la información obtenida del trabajo de Rodríguez y Urbina (s.f) y de las fincas estudiadas, se hace la prueba de comparación entre estos datos y los datos obtenidos en la ecuación (4), donde se observa el error entre estos dos valores (ver TABLA 7).

Con la información obtenida en la TABLA 7 se realiza una gráfica (Figura 11) en la cual se comparan los valores de la investigación y los valores obtenidos de la ecuación (4) del modelo matemático, donde se puede observar que la diferencia entre una y otra es mínima. Con esto cabe resaltar que la ecuación se adapta a los datos obtenidos en la investigación.

Para la producción de biogás se tiene en cuenta la cantidad de cerdos y los datos obtenidos en diferentes granjas donde se utiliza el biogás (Rodríguez \& Urbina, s.f). Para este también se procede a reemplazar valores en la ecuación matemática (5), con el fin de garantizar que el modelo matemático calculado se adapte a los datos obtenidos en la investigación. En la Tabla 8 se puede observar el error que existe entre los datos de la investigación y los que se obtienen de la ecuación (5).
Table 7. Test of the equation obtained for the mathematical model for production of pig manure / Prueba de la ecuación obtenida para el modelo matemático de producción de estiércol de cerdo

\begin{tabular}{rrrr}
\hline $\begin{array}{r}\text { Pig / } \\
\text { Cerdos } \\
(\#)\end{array}$ & $\begin{array}{r}\text { Manure / } \\
\text { Estiércol (kg) }\end{array}$ & $\begin{array}{r}\text { Biodigester size } \\
\text { / Tamaño del } \\
\text { biodigestor }\left(\mathrm{m}^{3}\right)\end{array}$ & $\begin{array}{r}\text { Volume of } \\
\text { biogas }\left(\mathrm{m}^{3} /\right. \\
\text { day })\end{array}$ \\
\hline 1 & 2.25 & 2.622788931 & 0,16 \\
2 & 5 & 4.838411699 & 3,23 \\
3 & 7.5 & 7.056102827 & 5,92 \\
6 & 13.5 & 13.72094283 & 1,64 \\
15 & 33.75 & 33.8069167 & 0,17 \\
24 & 54 & 53.99740302 & 0,00 \\
25 & 56.25 & 56.24554766 & 0,01 \\
39 & 87.75 & 87.77972458 & 0,03 \\
40 & 90 & 90.03475664 & 0,04 \\
83 & 186.75 & 186.7499792 & 0,00 \\
85 & 191.25 & 191.2223588 & 0,01 \\
200 & 450 & 447.9997 & 0,44 \\
\hline
\end{tabular}

Once these data are obtained, the mathematical model of the MES with B-EE is carried out, establishing as input variable the number of pigs held on a given farm (x), since they are the source of the raw material for the production of biogas.

Taking into account TABLES $\mathbf{4}$ and 5, it is proceed through the mathematical software tool Matlab to find an equation of the estimated amount of manure obtained from these data corresponding to equation (4); additionally, equation (5) corresponding to production of biogas was obtained, depending on the input variable.

$C_{E}=(31,19 * E-9) x^{4}+(11,1 * E-6) x^{3}-0.0011 x^{2}+2.2124 x+0.4093(4)$

Where:

$C_{E}:$ Amount of manure $[\mathrm{kg}]$

$x$ : Number of pigs on the farm [dimensionless]

Where:

$P_{B}=(134,99 * E-9) x^{4}+(43,62 * E-6) x^{3}+(3,8 * E-3) x^{2}+0.0832 x-0.3525(5)$

$P_{B}:$ Production of biogas [m3/day]

$x$ : Number of pigs on the farm [dimensionless]

With the information obtained from the work of Rodríguez and Urbina (n.d.) and the farms studied, a comparison test is performed between these data and the data obtained in equation (4), where the error between these two values is observed (see TABLE 7). 


\section{E Vs numero de cerdos (x)}

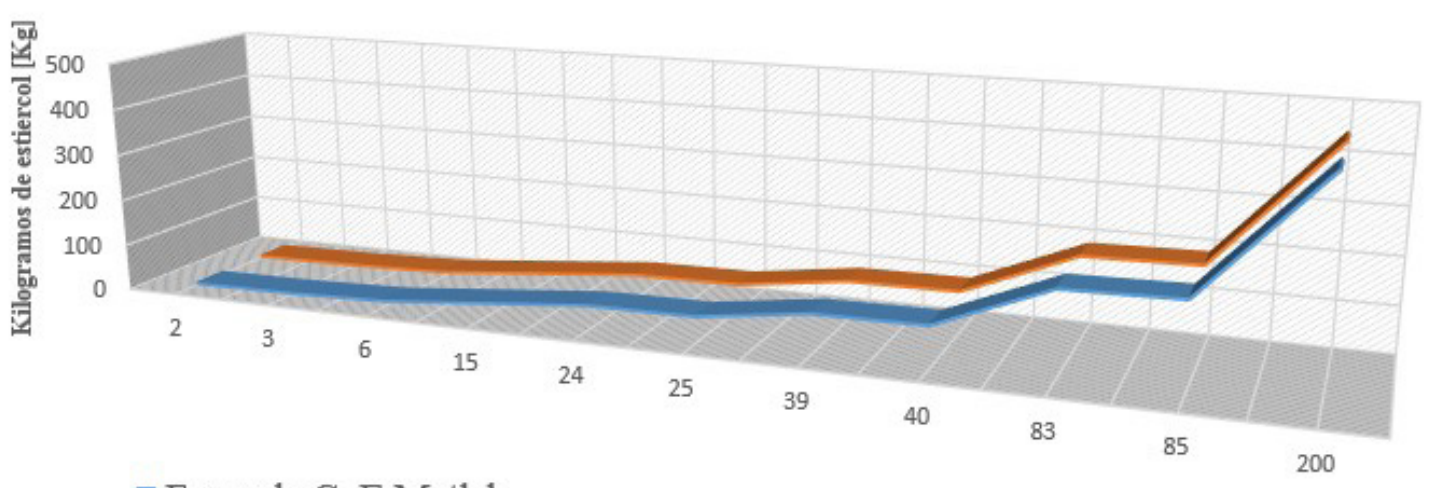

- Formula C_E Matlab

Número de cerdos

- Kilos de Estiercol

Figure 11. Comparison between research data and mathematical equation (4) /

Comparación entre datos de investigación y ecuación matemática (4)

With the information obtained in TABLE 7, a graph (FIGURE 11) is made in which the values of the research and the values obtained from equation (4) of the mathematical model are compared, where it can be observed that the difference between one and another is minimal. With this it is possible to emphasize that the equation is adapted to the data obtained in the investigation.

For the production of biogas, it is taken into account the number of pigs and the data obtained from different farms where biogas is used (Rodríguez \& Urbina, n.d.). For this one, it is also necessary proceeding to replace values in the mathematical equation (5), in order to guarantee that the calculated mathematical model is adapted to the data obtained in the research. In Table 8 it is possible to observe the error that exists between the data from the research and the data that is obtained from the equation (5).

From TABLE $\mathbf{8}$ it is proceed in the same way to make a graph in which are compared the data of production of biogas from farms and the equation (5) of the mathematical model. It also shows that the equation tends to give values that approach to the information established in the research.

For the use of the biogas, conventional generators are sought in order to work by means of this fuel, with a nominal power and the biogas consumption known for its operation. And now conventional generators are selected in which these data are known.
Table 8. Test of the equation obtained for the mathematical model for production of biogas / Prueba de la ecuación obtenida para el modelo matemático de producción de biogás

\begin{tabular}{rrrr}
\hline $\begin{array}{r}\text { Pig / } \\
\text { Cerdos } \\
\text { (\#) }\end{array}$ & $\begin{array}{r}\text { Biogas production } \\
\text { day }) / \text { Producción de biogás }\end{array}$ & $\begin{array}{r}\text { P_B Matlab for- } \\
\text { mula }\left(\mathrm{m}^{3} / \text { day }\right)\end{array}$ & Error $(\%)$ \\
\hline 1 & 0.28 & 0.439 & 0.56 \\
2 & 0.52 & 0.534 & 2.64 \\
3 & 0.65 & 0.635 & 2.29 \\
6 & 1.07 & 0.979 & 8.48 \\
15 & 2.2 & 2.315 & 5.23 \\
24 & 4 & 3.980 & 0.50 \\
25 & 4.25 & 4.179 & 1.68 \\
39 & 7 & 7.102 & 1.46 \\
40 & 7.31 & 7.314 & 0.06 \\
83 & 14.9 & 14.901 & 0.01 \\
85 & 15 & 15.138 & 0.92 \\
200 & 36 & 36.017 & 0.05 \\
\hline
\end{tabular}

A partir de la TABLA 8 se procede de igual forma a realizar una gráfica en la que se comparan los datos de la producción de biogás de las fincas y la ecuación (5) del modelo matemático. En ella también se observa que la ecuación tiende a dar valores que se acercan a la información establecida en la investigación.

Para el aprovechamiento del biogás se buscan generadores convencionales que funcionen por medio de este combustible, con una potencia nominal y el consumo de biogás conocido para su funcionamiento. A continuación, se seleccionan generadores convencionales en los cuales se conocen estos datos. 


\section{P_B Vs Numero de cerdos (x)}

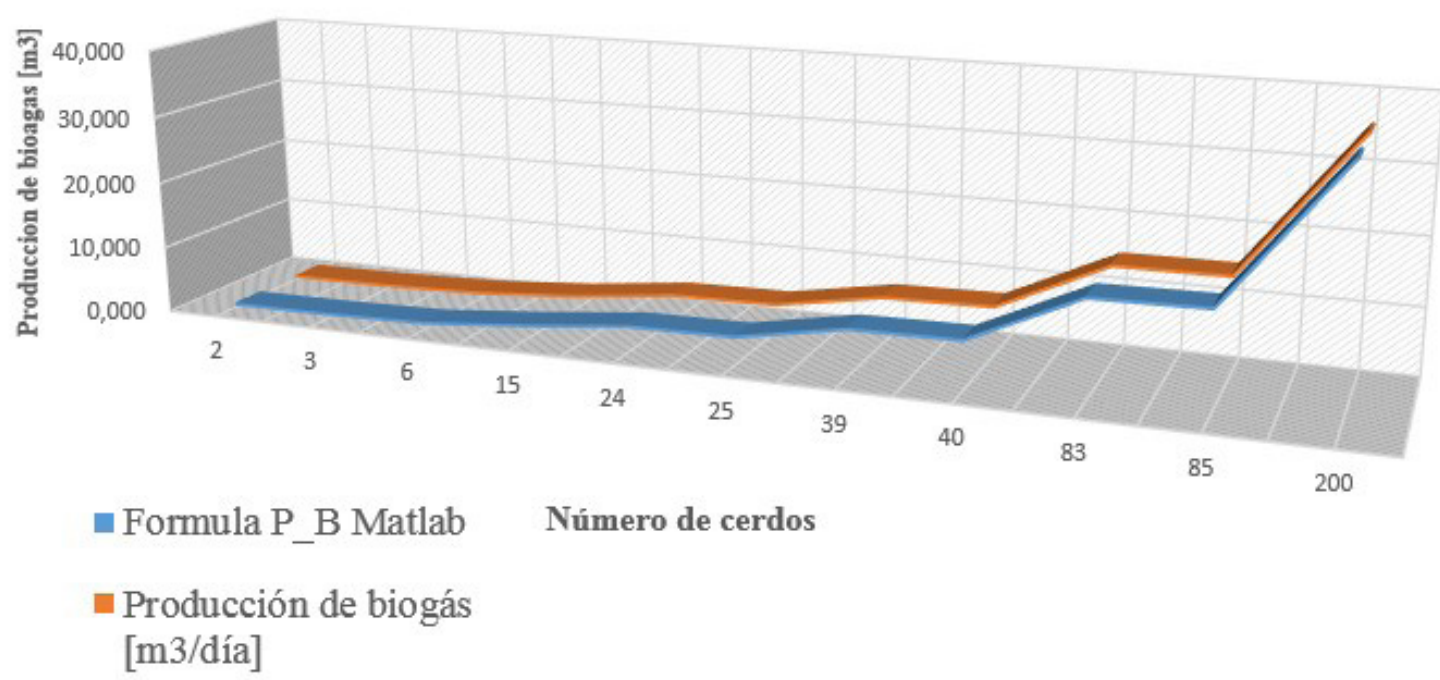

Figure 12. Comparison between the research data and the mathematical equation (5) /

Comparación entre los datos de investigación y la ecuación matemática (5)

En la Tabla 9 se muestra el consumo mínimo de biogás necesario para garantizar la potencia nominal. El modelo matemático del SME con B-EE, busca en este apartado una ecuación en la que se pueda obtener como resultado el tiempo de autonomía de un generador, dependiendo de sus especificaciones técnicas, en cuanto al volumen mínimo de biogás para su funcionamiento y de acuerdo con la cantidad de cerdos que se tenga.

El modelo matemático del SME con B-EE, con respecto de la autonomía del generador para la producción de energía eléctrica, se establece a continuación:

$$
P_{E}=\frac{P_{B}}{C_{M_{B}}}[\text { Hours a day }] \text { (6) }
$$

Table 9. Electric generators operating with biogas as fuel ("Cata$\log$...", 2016) / Generadores eléctricos que funcionan con biogás como combustible ("Catálogo...", 2016)

\begin{tabular}{rrrr}
\hline $\begin{array}{r}\text { Gene- } \\
\text { rator / } \\
\text { Generador }\end{array}$ & $\begin{array}{r}\text { Power } \\
\text { Potencia }) /\end{array}$ & $\begin{array}{r}\text { Biogas consump- } \\
\text { tion }\left(\mathrm{m}^{3} / \mathrm{h}\right) /\end{array}$ & $\begin{array}{r}\text { Price }(\mathrm{US} \$) / \\
\text { Consumo de biogás }\end{array}$ \\
\hline 1 & 1.2 & $0.55-0.65$ & $480-550$ \\
2 & 2.0 & $0.55-0.65$ & $300-900$ \\
3 & 2.0 & 0.35 & 600 \\
4 & 1.5 & 1.03 & 900 \\
5 & 3.5 & 2.10 & 900 \\
6 & 5.0 & 3.75 & 900 \\
7 & 20.0 & 0.36 & $6.350-18.000$ \\
\hline
\end{tabular}

TABLE 9 shows the minimum biogas consumption required to guarantee nominal power. In this section, the mathematical model of the MES with B-EE seeks for an equation in which the time of autonomy of a generator can be obtained, depending on its technical specifications regarding the minimum volume of biogas for its operation and according to the number of pigs available.

The mathematical model of the MES with B-EE, in relation to the autonomy of the generator for the production of electrical energy is established as follows:

$$
P_{E}=\frac{P_{B}}{C_{M_{B}}}[\text { Hours a day }] \text { (6) }
$$

Where:

$$
\begin{aligned}
& P_{E}: \text { Generator autonomy }[\mathrm{h}] \\
& P_{B}: \text { Daily production of biogas }[\mathrm{m} 3 / \text { day }] \\
& C_{M B}: \text { Minimum biogas consumption }[\mathrm{m} 3 / \mathrm{h}]
\end{aligned}
$$

For the case study of Villa Letty farm, it is possible determine the production of electrical energy, as follows: the number of pigs $(x)$ is six, then:

$$
x=6
$$

Isolating this value into equation (5) it is obtained the gas production of said farm:

$P_{B}=(134,99 * E-9) *(6)^{4}+(43,62 * E-6) *(6)^{3}+(3,8 * E-3) *(6)^{2}+0.0832 *(6)-0.3525$ 


$$
P_{B}=0.979\left[\frac{m^{3}}{d a y}\right]
$$

Then, this value is taken and replaced in equation (6) as follows, due to $C_{M B}$ is determined depending on the type of generator (a value of $0.55 \mathrm{~m} 3$ is chosen arbitrarily):

$$
P_{E}=\frac{P b}{C_{M_{B}}}=\frac{0.979}{0.55}=1.78[\text { Hours a day }]
$$

Then, conversion is performed to know how much time actually equals to the data obtained.

$$
\begin{gathered}
P_{E R}=P_{E} * 60[\text { minutes }] \\
P_{E R}=1.78 * 60[\text { minutes }] \\
P_{E R} \approx 106[\text { minutes }]
\end{gathered}
$$

That is, in Villa Letty the quantity of pigs allows to cover the nominal power of the generator for two hours a day.

According to the mathematical model developed for MES with B-EE for farms with small amounts of pigs, it does not achieve a considerable level of autonomy by the generator; therefore, to establish an autonomy that fulfills a time of 24 hours (1440 minutes), the quantity of pigs is isolated.

$$
\begin{gathered}
P_{E}=24[\text { Hours a day] } \\
P_{B}=P_{E} * C_{M_{B}} \\
P_{B}=24 * 0,55 \\
P_{B}=13,2
\end{gathered}
$$

Isolating equation (5) gives an approximate value of the amount of pigs that a farm must have in order to have autonomy for 24 hours. With 6 pigs it is possible to have two hours of generation; it is required to have 35 pigs to have 12 hours; and 71 or 72 pigs, to have supply throughout the day.

\section{VIl. Conclusions}

The biodigester is an alternative for the production of renewable sources that mitigate the effects produced by the use of fossil fuels and the exploitation of non-renewable resources. In several rural areas of Cundinamarca, there is livestock activity, specifically pig farming, which generates incentives for the implementation of biodigesters technology that works from organic wastes of swine origin, which have great energetic potential.

Some areas of Cundinamarca that practice pig farming are not part of NIS, therefore, the production of electrical
Dónde:

$P_{E}:$ Autonomía del generador [h]

$P_{B}$ : Producción de biogás diaria [m3/día]

$C_{M B}$ : Consumo mínimo de biogás $[\mathrm{m} 3 / \mathrm{h}]$

Para el caso de estudio de la finca Villa Letty, se puede determinar cuál será la producción de energía eléctrica, de la siguiente forma: la cantidad de cerdos $(x)$ es seis, entonces:

$$
x=6
$$

Despejando este valor en la ecuación (5) se obtiene la producción de gas en dicha finca:

$P_{B}=(134,99 * E-9) *(6)^{4}+(43,62 * E-6) *(6)^{3}+(3,8 * E-3) *(6)^{2}+0.0832 *(6)-0.352$

$$
P_{B}=0.979\left[\frac{m^{3}}{d a y}\right]
$$

Luego se toma este valor y se reemplaza en la ecuación (6) de la siguiente manera, debido a que el $C_{M B}$ está determinado dependiendo del tipo de generador (se escoge arbitrariamente un valor de $0,55 \mathrm{~m} 3)$ :

$$
P_{E}=\frac{P b}{C_{M_{B}}}=\frac{0.979}{0.55}=1.78[\text { Hours a day }]
$$

Se realiza entonces la conversión para saber cuánto tiempo equivale en realidad el dato obtenido.

$$
\begin{gathered}
P_{E R}=P_{E} * 60[\text { minutes }] \\
P_{E R}=1.78 * 60[\text { minutes }] \\
P_{E R} \approx 106[\text { minutes }]
\end{gathered}
$$

Es decir, en Villa Letty, la cantidad de cerdos permite abarcar la potencia nominal del generador durante dos horas al día.

De acuerdo con el modelo matemático desarrollado para el SME con B-EE para granjas con pequeñas cantidades de cerdos, no logra un nivel considerable de autonomía por parte del generador; por tanto, para establecer una autonomía que cumpla un tiempo de 24 horas (1440 minutos), se despeja entonces la cantidad de cerdos necesaria.

$$
\begin{gathered}
P_{E}=24[\text { Hours a day }] \\
P_{B}=P_{E} * C_{M_{B}} \\
P_{B}=24 * 0,55 \\
P_{B}=13,2
\end{gathered}
$$

Despejando en (5) se obtiene un valor aproximado de la cantidad de cerdos que debe tener una granja para contar con una autonomía de 24 horas. Con 6 cerdos es posible 
tener dos horas de generación, se requieren 35 para 12 horas; y 71 o 72 , para tener suministro durante todo el día.

\section{Conclusiones}

El biodigestor es una alternativa para la producción de fuentes renovables que mitiguen los efectos producidos por el uso de combustibles fósiles y la explotación de los recursos no renovables. En varias zonas rurales de Cundinamarca existe actividad pecuaria, específicamente manejo de ganado porcino, lo que genera incentivos para la implementación de la tecnología de biodigestores que funcionen a partir de desechos orgánicos de origen porcino, los cuales tienen gran potencial energético.

Algunas zonas de Cundinamarca que practican la porcicultura no hacen parte del SIN, por tanto, la producción de energía eléctrica a partir del biogás como material combustible, es una alternativa energética viable en ellas.

Para una mayor eficiencia en la producción de energía y el aprovechamiento óptimo de los equipos es necesario establecer de manera correcta los parámetros, tanto del biodigestor (dimensionamiento, capacidad de carga, material orgánico, condiciones ambientales, distribución de los equipos, producción de biogás, entre otros), como del generador (potencia nominal, voltaje y frecuencias nominales, tipo de combustible, entre otros).

Con el modelo obtenido se puede hacer un estimativo aproximado de la cantidad de biomasa orgánica necesaria para abastecer la finca durante un determinado número de horas del día, dependiendo de la cantidad de cerdos que se tienen en la granja, conociendo las cargas que se van a conectar al generador y teniendo en cuenta los parámetros necesarios para que el biodigestor pueda realizar su proceso de fermentación y entregar el biogás necesario para que el generador suministre energía en condiciones normales. De esta manera se evitan sobredimensionamientos.

Como se pudo observar, el modelo matemático del SME con B-EE se adapta a la realidad, de acuerdo con los parámetros que se tuvieron en cuenta en esta investigación.

Una de las consecuencias de la falta de apropiación de conocimientos y saberes de las comunidades es que desconocen que pueden utilizar de puente a la academia para diseñar, desarrollar e implementar energías alternativas con las materias orgánicas que no se utilizan de manera eficiente.

Analizando el modelo obtenido por medio de datos de los casos de estudio, se llega a una estimación aproximada de la cantidad de cerdos necesarios para brindar durante cierto intervalo de tiempo la autonomía que se le quiera dar al generador. SeT energy from biogas as a combustible material, is a viable alternative energy for them.

For greater efficiency in energy production and optimal use of equipment, it is necessary to establish correctly the parameters of the biodigester (dimensioning, load capacity, organic material, environmental conditions, equipment distribution, biogas production, among others), and the generator (nominal power, nominal voltage and frequencies, fuel type, among others).

With the obtained model, it is possible to make an approximate estimate of the amount of organic biomass necessary to supply the farm during a certain number of hours a day depending on the amount of pigs that are in the farm, knowing the loads that are going to be connected to the generator and taking into account the necessary parameters so the biodigester can perform its fermentation process and deliver the necessary biogas for the generator to supply energy under normal conditions. This will avoid oversizing.

As it can be observed, the mathematical model of the MES with B-EE adapts to the reality, according to the parameters that were taken into account in this research.

One of the consequences of the lack of appropriation of knowledge of the communities is that they do not know that they can use as a bridge the academy to design, develop and implement alternative energies with the organic materials that are not used efficiently.

Analyzing the model obtained by means of data from the case studies, it is possible to reach an approximate estimation of the number of pigs necessary to provide for a certain interval of time, the autonomy that is wanted to be given to the generator. $\mathbf{S} T$ 


\section{References / Referencias}

Catálogo de fabricantes. (2016). Retrieved from: https://spanish.alibaba.com/g/2kw-bio-gas-generator_2.html

Chapman, S. (2000). Maquinas eléctricas. Ciudad de México: McGraw-Hill.

Gonzaga, D. A. , Barbosa, R. C. (2014). Estimativa do tamanho mínimo de rebanho suíno para a implementação de sistema de geração de energia elétrica de 35 kwh, 150 kwh, 275 kwh e 590 kwh, usando biogás como combustível para grupos geradores. In XLIII Congresso Brasileiro de Engenharia Agrícola - CONBEA 2014. Retrieved from: http://www.sbea.org.br/ conbea/2014/anais/R0223-1.pdf

Guerrero, L. (2016, Feb. 26). ¿Qué es un biodigestor? Retrieved from: http://vidaverde.about.com/od/Energias-renovables/a/ Que-Es-Un-Biodigestor.htm

Hilbert, J. (2011). Manual para la producción de biogás. Retrieved from: http://inta.gob.ar/sites/default/files/script-tmp-manual_para la produccin de biogs del iir.pdf

Instituto Geográfico Agustín Codazzi [IGAC]. (2016). Territorio y estadísticas catastrales. Retrieved form: http://www.igac.gov. co/igac

Olaya, Y. \& González, L. (2009). Fundamentos para el diseño de biodigestores. Palmira, Colombia: Universidad Nacional de Colombia.

Rodríguez, D. \& Urbina, A. (s.f.). Biodigestores: ¿Qué son y cómo construirlos? Retrieved from: http://www.mag.go.cr/bibliotecavirtual/prog-cerdos-biodigestor1.pdf 


\section{CURRICULUM VITAE}

Oscar Iván Galvis Cabrera Electrical Engineering student at the Universidad Distrital Francisco José de Caldas (Bogotá, Colombia) / Estudiante de pregrado de Ingeniería Eléctrica de la Universidad Distrital Francisco José de Caldas (Bogotá, Colombia).

Cristian Arturo Lee Capera Electrical Engineering student at the Universidad Distrital Francisco José de Caldas (Bogotá, Colombia) / Estudiante de pregrado de Ingeniería Eléctrica de la Universidad Distrital Francisco José de Caldas (Bogotá, Colombia).

Claudia María Cardona Londoño, MSc. Agricultural Engineer and Master in Exploitation of Water Resources from the Universidad Nacional de Colombia (Medellín), with Specialization in University Teaching from the Universidad El Bosque (Bogotá, Colombia). She is teacher at the Universidad Distrital Francisco José de Caldas (Bogotá, Colombia). She is a researcher focused in watershed management and water resources / Ingeniera Agrícola y Máster en Aprovechamiento de Recursos Hídricos de la Universidad Nacional de Colombia (Medellín), con Especialización en Docencia Universitaria de la Universidad El Bosque (Bogotá, Colombia). Es docente de la Universidad Distrital Francisco José de Caldas (Bogotá, Colombia). Su principal área de interés en investigación es el manejo de cuencas hidrográficas y de recursos hídricos.

Johann Alexander Hernandez Mora, Ph.D. Electrical Engineer, Master and PhD in Electrical Engineering from the Universidad Nacional de Colombia (Bogotá). His research interests include photovoltaic systems, energy efficiency, solar energy and distributed generation. He is a full professor at the Universidad Distrital Francisco José de Caldas (Bogotá, Colombia) / Ingeniero Eléctrico, con Maestría y Doctorado en Ingeniería Eléctrica de la Universidad Nacional de Colombia (Bogotá). Sus áreas de interés en investigación incluyen los sistemas fotovoltaicos, la eficiencia energética, la energía solar y la generación distribuida. Es docente de tiempo completo de la Universidad Distrital Francisco José de Caldas (Bogotá, Colombia). 